\title{
The Effect of TQM on firm Performance: Empirical Study in Jordanian Private Airlines
}

\author{
Adnan M. Rawashdeh ${ }^{1}$ \\ ${ }^{1}$ The University of Jordan, Jordan \\ Correspondence: Adnan M. Rawashdeh, The University of Jordan, Jordan. E-mail: adnanrawa@yahoo.com
}

Received: July 8, 2018

Accepted: August 8, 2018

Online Published: August 21, 2018

doi:10.5539/mas.v12n9p140

URL: https://doi.org/10.5539/mas.v12n9p140

\begin{abstract}
The purpose of this study was to explre the relationship between total quality management and firm performance, i.e. quality, business and organizational performance in Jordanian private airlines. The design of this study has a quantitative approach. Data was obtained by questionnaire instrument. The respondents of this study are all employees in quality department, maintenance department, human resource department, and operation department. The number of population was 480 employees. Random sampling was used in the study. 340 completed questionnaires were analyzed as a final sample. Three hypotheses have been developed through literature review and tested using descriptive statistical analysis performed by SPSS. The results show that total quality management practices have a positive and significant impact on business, quality, and organizational performance in Jordanian private airlines. The study reports that effective implementation of total quality management practices results in enhancing airline performance. The major limitation of this study is that the study asked for perceived data about actual TQM practices and performance measures, but the respondents might have given desired data, which made their companies sound good, most of the respondents were non managers and from different departments in addition to the quality department, who might not understand to answer the questions accurately. Another limitation was that business performance tenets were measured by using one question per each tenet. Future research may investigate those TQM practices and performance measures in another Jordanian industry.
\end{abstract}

Keywords: TQM practices, airline performance, aviation industry, Jordan

\section{Introduction}

Today, the global business marketplace has become very competitive; organizations are on a quest to a significant change in the way they conduct their businesses, which can provide and sustain an edge over competitors (Ray et al., 2016; Hassan et al., 2012). Sustainability has been emerged as the biggest question mark for business organizations in this fast-growing competitive environment. Therefore, in order to survive in this competitive environment, all business organizations need to promote their level of competence (Korankye,2013). Organizations can improve their competence by implementing total quality management strategy in their business model. The quality management system within the organization can be recognized as the reason for the success or failure of the business (Hossain et al., 2017). According to Zehir et al. (2012), total quality management has turned out to be a boundless over several companies during the last two decades as it has been confirmed as a key source of maximizing firms' value in the long run. It has contributed significantly to the development of management practices (Ali\&MIMechE, 2014). TQM has also been recognized as a new way of managing firms to stimulate performance and competitiveness (Bahri et al., 2012). Furthermore, total quality management can be achieved and become as a part of overall organizational philosophy with its core values centered on continuous improvment of all quality aspects of whole products, services, processes, and employees of the firm (Rawashdeh,2014). It aims at providing competitive position by increasing the satisfaction levels through cost effectiveness (Musran, 2013). In other words, the implementation of total quality management may help organizations to deliver a high-quality products or services to customers at a fair cost. Now, Jordanian private airlines have envisioned adopting total quality management in their operations to help deliver a high quality, low-cost services in order to meet customer requirements and enjoying positive performance. In this regard, no study has been conducted to explore the significant association between total quality management practices and firm performance in Jordanian private airlines particularly the different dimensions of performance such as business, quality, and organizational performance. A better understanding of this relationship may contribute to the theory and practice of the aviation 
industry and also to provide further insight to the effect of total quality management on airline performance. To fill this gap of strategic importance, this study emerged as an attempt to investigate the impact of total quality management practices on quality, business and organizational performance in Jordanian private airlines.

\section{Literature Review}

The word "quality" is derived from the Latin word " qualitas" which means "essential nature." (Bergman\& Klefsjö, 2010). The evolution of total quality emerged as a series of steps such as inspection, quality control, quality assurance, quality management and total quality management in addition to some practices such as; supply chain management and new metrologies that were traced to originate from Motorola- six sigma (Chibba, 2017). Inspection is an organized examination measurement to ensure that products or services meet customer expectation; quality control is a method that is applied as a part of self-inspection; quality assurance is a process centered on the continuous improvement of systematic planning and prevention of mistakes or defects from happening at the root cause; quality management is a mechanism of ensuring that all activities are used to maintain a desired level of excellence; finally, TQM (Total Quality Management) is recognized as the ultimate level that compose of various applications of quality functions to the whole aspects of the organization including customer, supplier and their integration with the main business process (Dale,2003). Total quality management has been the most prominent and visible method of quality development from the work of Deming and the early quality gurus. It emerged in the 1980s as a Japanese management tool to enhance quality and become more popular during the 1990 (Zakuan, 2010). Although, it is a philosophy of managing firms that seeks to improve their quality and performance in oreder to meet customer needs and expectations and enjoying long-term success. It also requires an active involvement, participation, and cooperation from all people within the firm or it will fall short of its objective in meeting customer's expectations (Hung et al., 2011). Several firms have been benefited from the effective implementation of total quality management, especially large firms, such as IBM, General Motors, Motorola, Rank Xerox as they are considered as benchmarks including many whose functions have directly affected modern models of total quality management (Benavent, 2006; Jabnoun\&Sedrani, 2005, Welch, 2005, Ahire \& Golhar, 1996). Total Quality Management can be defined as an approach of stimulating working environment through continuous imrovement that attempts to fulfilling and meeting or exceeding customer needs and expectations (Bergman \& Klefsjö, 2010). Rad (2006) described total quality management as a process of continuous improvement that concentrates on customer satisfaction by offering quality products at lower cost. Al-Damen (2017) argued that total quality management is considered as a part of overall organizational culture adopted by people in order to satisfy the valued customer. Oakland (2000) defined TQM as a process of meeting customer requirements that include, availability, reliability, delivery, maintainability, and cost effectiveness, among any other feature. Additionally, much work has been done on different types of total quality management practices in different fields. Azizan (2007) adopted eight factors to measure the performance of TQM in an organization. These factors include customer focus, leadership, involvement of people, process approach, systems approach to management, continual improvement, factual approach to decision making, and mutually beneficial supplier relationship. Black \& Porter (1996) suggested some factors such as communication improvement information, strategic quality management, corporate quality culture, quality improvement measurement system, teamwork structure, customer satisfaction orientation, supplier partnership, external interface management, people and customer management, and operational quality planning. Escrig-Tena (2004) stated that quality practices are mutually interrelated and designed to support each other, which include continuous improvement, focus on people, customer satisfaction, and global vision of the firm. Al-Damen (2017) investigated cost focus, leadership, continuous improvement, employees' involvement, fact-based management, process management, strategic management, and supplier involvement in Jordan petroleum refinery and they produced positive outcomes. Flynn et al. (1994) suggested top management support, process management, quality information, product design, customer involvement, supplier involvement, and workforce management. Motwani (2001) applied four factors that include customer involvement and satisfaction, quality measurement and benchmarking, employee training and process management. Sila \& Ebrahimpour (2005) proposed people management, customer focus, process management, information and analysis, leadership, supplier management, and strategic planning.

From the description above, it is recognized that the TQM practices is selected with accordance to the objective of each study. So, the TQM functions construct used in this study involves supplier management, customer focus, leadership, process management, information and analysis, people management, continuous improvement, and strategic planning.

Performance measurement is considered as a quantifiable indicator used to assess results and outcomes which produce reliable data on the efficiency and effectiveness of programs (Hung et al,2011). It is very important for the effective management of organizations, and it refers to how well companies can achieve their objectives (Li et 
al., 2006). Many studies have investigated the relationship between TQM practices and various performance measures and they have adopted diversified measures of performance with different indicators. Fuentes et al. (2006) assessed organizational performance from operational performance, market and financial performance, and employee performance. Yang (2006) proposed employee satisfaction and customer satisfaction to measure quality performance. Sila (2007) used employee satisfaction, customer satisfaction and process to assess quality performance. Zakuan et al. (2010) proposed employee performance that composed of employee satisfaction, customer's satisfaction, and business results to evaluate business performance. Stock et al (2000) applied business performance that consisted of return on investment (RIO), market share, and sales. Zhang (2000) used employee satisfaction, product quality, customer satisfaction and strategic business performance to investigate business performance. Fotopoulus et al. (2009) proposed sales level, cost, and revenue to evaluate business performance. Sang (2005) suggested firm performance with employee efficiency, employee turnover, employee performance, operational performance, financial performance, economic performance, customer satisfaction level, market share,and profitability. Ali \& MIMechE (2014) poisted people results, client results, society results, and key performance results to assess business performance. Way \& Johnson (2005) pointed out corporate performance outcomes that measure human span resources (employee withdrawal, workforce, employee satisfaction), operational (service, productivity, quality), financial (return on investment, sales growth, profitability) and capital market (shareholder return, stock value) outcomes. Musran (2013) proposed financial performance with indicators, return on investment, market share, profit margin on sales, ROI growth, sales growth, and market share growth. Prajogo (2005) stated that quality performance composed of processes, product/service cost, and delivery time. However, the previous work did not show much evidence on the level of improvement of different dimensions of performance caused by the implementation of total quality management. Therefore, to measure the effect of TQM practices on various levels of improvement, this paper includes different dimensions of performance with different indicators such as, quality performance (defects rate, rework, cost per product, customer complaint, cycle time and delivery time), business performance (market share, net profit and increase in total sales) and organizational performance (reduction in absenteeism, improvement in skills level, reduction in tardiness rate, improvement in employees attitude toward quality, and improvement of flow of information among departments). Many studies have been carried out and found a positive association between these performance dimensions and total quality management. (Kumar et al, 2009; Yang, 2006; Zehir et al., 2012; Sila, 2006; Prajogo, 2005; Hassan et al. , 2012) found a positive and strong association between TQM practices and quality performance.(Hassan et al., 2012; Ali\& MIMechE, 2014; Stock et al., 2000; Huarng \& Chen, 2002; Gadenne \& Sharma, 2002) reported positive relationship between TQM implementation and business performance. (Fuentes et al., 2006; Hassan et al., 2012; Brah \& Lim, 2006; Feng et al., 2006, Hossain et al., 2017; Rawashdeh, 2014) found positive impact of TQM applications on organizational performance).

\section{Research Hypotheses}

After reviewing literatures, this quantitative study provides the following hypotheses:

H1.Total quality management is more likely to have a positive impact on quality performance in Jordanian private airlines.

H2. Total quality management is more likely to have a positive impact on business performance in Jordanian private airlines.

H3. Total quality management is more likely to have a positive impact on organizational performance in Jordanian private airlines.

\section{Research Method}

Questionnaire survey was used to collect primary data from the research sample. Respondents were permanent employees from different departments such as quality, maintenance, human resources, and operations as they have the best knowledge about the quality management in airlines. The information about the airlines was obtained from Jordanian civil aviation regulatory commission. The population of this study consists of 12 Jordanian private aviation companies. As many as 480 questionnaires were submitted directly by the researcher to airline sample. A total of 392 questionnaires were received until the end of survey, and after deep investigation, a number of 52 questionnaires were found unfit for the statistical analysis. Therefore, a total of 340 questionnaires were used in the analysis process which were considered as the study sample. Stratified sampling was applied in this study and the sample size was chosen according to the population of company, then the sample was selected randomly. The data were then analyzed using statistical package for social science (SPSS 20). The questionnaire was in three segments. Segment A contains information about respondents such as, organizational tenure, education, age, gender, and length of service in aviation industry. Segment B contains information on independent variable- total 
quality management practices (supplier management, customer focus, leadership, process management, information and analysis, people management, continuous improvement, and strategic planning). Segment $\mathrm{C}$ tackles questions on dependent variable- quality performance dimensions (defect rate, rework, cost per product, customer complaint, cycle time and delivery time), business performance (market share, net profit and increase in total sales) and organizational performance (reduction in absenteeism, improvement in skills level, reduction in tardiness rate, improvement in employees attitude toward quality, and improvement of flow of information among departments). The respondents were asked to indicate their response to the questions on a five-point Likert scale ranging from 1 (strongly disagree) to 5 (strongly agree). The items used in this study were adopted from different studies (Kumar et al., 2009; Zehir et al., 2012; Prajogo, 2005; Hassan et al., 2012) ; Stock et al., 2000; Huarng \& Chen, 2002; Gadenne \& Sharma, 2002; Fuentes et al ,2006; Brah \& Lim, 2006; Feng et al, 2006, Hossain et al, 2017). The instrument was pilot tested using 40 employees from the study population. It has showed high validity as the correlation values of the indicators to total correlation ranged from $0.58-0.76<0.50(\mathrm{Wu}, 2005)$. Reliability of the constructs was tested with Cronbach's Alpha as suggested by Hair et al. (1998), the values for Cronbach's Alpha ranged from $0.67-0.82>0.60$. Thus, it can be concluded that the instrument used in this study was valid and reliable.

Table 1. Scale determination of the relative importance of the mean

\begin{tabular}{ll}
\hline \multicolumn{1}{c}{ The level of the effect } & The mean \\
\hline Low & 2.33 and less \\
Medium & $2.34-3.67$ \\
High & $3.68-5$ \\
\hline
\end{tabular}

These categories were derived according to the following equation:

Interval length $=($ highest weight - lowest weight $) /($ three levels $)=(5-1) / 3=1.33$

Table 2. The mean and standard deviation for the survey items in Jordanian private Airlines

\begin{tabular}{lccl}
\hline Category & Mean & Std. Dev. & Level \\
\hline TQM practices & & & \\
\hline Supplier management & 2.53 & 1.17 & Medium \\
Customer focus & 3.84 & 1.26 & High \\
Leadership & 2.38 & 0.94 & Medium \\
Process management & 2.41 & 1.22 & Medium \\
Information and analysis & 2.13 & 1.15 & Low \\
People management & 2.44 & 1.30 & Medium \\
Strategic planning & 4.02 & 1.28 & High \\
Continuous improvement & 3.66 & 1.18 & Medium \\
\hline Average TQM practices & 2.92 & 1.18 & Meduim \\
& & & \\
Quality performance & & & \\
\hline Defects Rate & 4.53 & 1.33 & High \\
Rework & 3.62 & 1.23 & Medium \\
Cost per product & 3.84 & 1.27 & Medium \\
Customer complaint & 4.24 & 0.86 & High \\
Cycle time & 4.33 & 096 & High \\
Delivery time & 4.66 & 1.18 & High \\
\hline Business performance & & & \\
\hline Market share & 4.20 & 1.15 & High \\
Net profit & 4.00 & 1.23 & High \\
Increase in total sales & 4.18 & 1,28 & High \\
\hline Organizational performance & & & \\
\hline Reduction in absenteeism & 4.61 & 1.25 & High \\
Improvement in skills level & 4.13 & 1.13 & High \\
& & &
\end{tabular}




\begin{tabular}{llll} 
Reduction in tardiness rate & 2.23 & 0.60 & Low \\
Improvement in employee attitude toward quality & 3.42 & 0.58 & Medium \\
Improvement of information flow among departments & 3.33 & 1.14 & Medium \\
\hline
\end{tabular}

Table 3. The correlation between survey items

\begin{tabular}{lllll}
\hline & Quality & Business & Organizational & TQM \\
\hline Quality & 1 & $0.52^{* *}$ & $0.58^{* *}$ & $0.61^{* *}$ \\
Business & & 1 & $0.74^{* *}$ & $0.82^{* *}$ \\
Organizational & & & 1 & $0.88^{* *}$ \\
TQM & & & & 1 \\
\hline
\end{tabular}

**. Correlation is significant at the 0.01 level (2-tailed).

Table 4. Full regression model between dependent variable and independent variables

\begin{tabular}{lllll}
\hline Model & $\mathrm{B}$ & Std. Error & $\mathrm{T}$ & Sig. \\
\hline Constant & -0.058 & 0.214 & -0.263 & 0.851 \\
Quality performance & 0.661 & 0.052 & 10.874 & 0.012 \\
Business performance & 0.443 & 0.056 & 4.682 & 0.034 \\
Organizational performance & 0.148 & 0.068 & 2.133 & 0.006 \\
R2 & 0.742 & & & \\
Adjusted R2 & 0,734 & & & \\
F test & 114.226 & & & \\
Sig & 0.000 & & & \\
\hline
\end{tabular}

\section{Results and Discussion}

Data was analyzed through descriptive statistical methods with mean, standard deviation, percentage, Pearson correlation coefficient, T-test, and regression. The results of descriptive statistical analysis indicated a general agreement of the respondents to total quality management. . The total implementation of TQM practices is 2.92, which is considered as a moderate level.The mean values ranged from highest 4.02 to lowest 2.13. The results for strategic planning indicated highest conformity $(\mathrm{Mean}=4.02$, Standard Deviation $=1.28)$; and information and analysis as lower indicator (Mean $=2.13$, Standard Deviation $=1.15$ ); quality performance, delivery time indicated highest conformity $($ Mean $=4.66$, Standard Deviation $=1.18)$ and rework as lower indicator $($ Mean $=3.62$, Standard Deviation $=1.23$ ); business performance, market share indicated the highest conformity $($ Mean $=4.20$, Standard Deviation $=1.15$ ) and net profit as lower indicator $($ Mean $=4.00$, Standard Deviation $=1.23$ ); organizational performance, reduction in absenteeism indicated highest conformity (Mean= 4.61, Standard Deviation $=1.25$ ) and reduction in tardiness rate as lower indicator (Mean=2.23, Standard Deviation=0.60). The mean score and standard deviation reflected conformity of respondents' perception about these strategies. The results of the multiple linear regression analysis in table (4) are indicating support for all the hypotheses. To test hypothesis 1 , correlation coefficient in table $3,(0.61)$ suggests a high positive association between total quality management practices and quality performance. The $\mathrm{T}$ value in table 4 (10.87) indicated that there is a significant relationship of total quality management practices with quality performance as the value of the significance level (0.012) related to $T$ value was less than 0.05 suggesting the presence of the relationship. The statistical analysis of hypothesis 1 confirms that the implementation of total quality management practices may provide firms with highquality performance on cost, rework, defect rate, customer retention, and delivery time. Given the fact, that TQM was originally intended for the achievement of quality performance can be considered as the intended effect resulting from the adoption of TQM. To test hypothesis 2 , correlation coefficient in table $3,(0.82)$ suggests a high positive association between total quality management practices and business performance. The $T$ value in table 4 (4.68) indicated that there is a significant relationship between total quality management practices and business performance as the value of the significance level $(0.034)$ related to $T$ value was less than 0.05 suggesting the presence of the relationship. The statistical significance of hypothesis 2 means that the implementation of total quality management practices may improve firms' financial and marketing performance in the long run. To test hypothesis 3 , correlation coefficients in table $3,(0.88)$ suggests a high positive association between total quality management practices and organizational performance. The $T$ value in table $4,(2.13)$ indicates that there is a significant relationship between total quality management practices and organizational performance as the value of significance level (0.006) relating to $T$ value was less than 0.05 suggesting the presence of the relationship. The 
statistical analysis of hypothesis 3 confirms that the implementation of total quality management practices may directly improve organizational performance,on employees' skills, reduction in absenteeism, improvement of employees' attitude toward quality, and improvement of the flow of information among departments. This may be true as TQM implementation success is determined by the support of organizations and strong relationships between employees (co-workers). Generally, top management in Jordanian private airlines have recognized total quality management as a priority for the survival and competition of their airlines. They have taken a long-term view of this significant issue, knowing that the successful adoption of these practices may lead to high-quality service and positive firm performance. As a result, they maintained to engage their airlines to TQM practices at all levels of the company. The positive results provided concrete evidence concerning the success of total quality management practices on airlines overall performance in aviation industry. TQM is considered as a process of managing and enhancing, flexibility, efficiency, competitiveness and effectiveness of the entire firm. Quality control, quality assurance and quality management are all embodied in total quality management together with all other management activities. This requires firms at all levels to commit to the standard operating procedure in order to ensure that every aspect of its activity is aligned to satisfy customer needs and expectations. TQM also, if practiced effectively, may provide firms with a variety of advantages such as improvement in the aspect of people efficiency and machines, fewer errors \& defects, continuous improvement of processes and products, better problem solving, improved customer satisfaction, better customer understanding, cost saving profitability improvement, and improved internal communication. The proper implementation of TQM in the overall firm is considered as a strategic weapon that can be used to outperform competitors in the marketplace. Thus, the effective implementation of TQM practices is a valuable asset in any organization and may produce positive corporate performance and competitive advantage. In a nutshell, total quality management practices, mostly, has been associated directly with improved corporate performance and sustainable competitive advantage.

The above mentioned findings are in conformity with previous studies results (Kumar et al, 2009; Zehir et al, 2012; Prajogo, 2005; Hassan et al ,2012) who found positive and strong association between TQM practices and quality performance, (Hassan et al , 2012; Stock et al, 2000; Huarng \& Chen, 2002; Gadenne \& Sharma, 2002) they reported positive relationship between TQM implementation and business performance, (Fuentes et al ,2006; Hassan et al, 2012; Brah \& Lim, 2006; Feng et al, 2006, Hossain et al, 2017, Rawashdeh, 2014) they found positive impact of TQM applications on organizational performance.

\section{Conclusion}

In the past several years, the contribution of total quality management as a key factor for organizational success has been well recognized and acknowledged. Organizations are using TQM to acheive competitive advantage over competitors. They aimed to provide a high quality products and services in order to meet customer needs and expectations. The objective of this study was to test the relationship between total quality management practices, quality performance, business performance and organizational performance in Jordanian private airlines. Previous studies asserted a positive and significant effect of total quality management on quality performance, business performance and organizational performance. And this study empirically confirmed the findings of these studies. In a nutshell, this study has been conducted in Jordanian private airlines and found a positive association between total quality management practices, quality performance, business performance and organizational performance. Nowadays, TQM becom a very important source of positive performance and competitive advantage. So, airline's management shall ensures that investing substantial resources in adapting and implementing total quality management practices in their operations would be valuable to create and sustain superior airline performance.

The major limitation of this study is that the study asked for perceived data about actual TQM practices and performance measures, but the respondents might have given desired data, which made their companies sound good, most of the respondents were non managers and from different departments in addition to quality department, who might not understand and answer the questions accurately. Another limitation was that business performance tenets were measured by using one question per each tenet. Future research may investigate those TQM practices and performance measures in other Jordanian industries.

\section{References}

Ahire, S., \& Golhar, D. (1996). Quality Management in Large vs Small Firms. Journal of Small Business Management, 34(2), 121-135.

Alaa, M., \& James, S. (1996). The Changing Basis of Performance Measurement. International Journal of Operations \& Production Management, 16(8), 63-80. https://doi.org/10.1108/01443579610125787

Al-Asiri, M. (2004). Factors Affect the Practices of ISO 9001:2000 Quality Management System in Saudi Business Organizations, Ph.D. Thesis, University of Central Florida. 
Al-Damen, R. (2017). The impact of Total Quality Management on organizational performance Case of Jordan Oil Petroleum Company. International Journal of Business and Social Science, 8(1), 192-2002.

Ali, S., \& MIMechE, I. (2014). Impact of Quality Management On Organizational Performance. International Journal of Scientific and Technology Research, 3(8), 271-282.

Azizan, A. (2007). A Study of TQM Application by Malaysia SMEs, PhD thesis, Cardiff University.

Bahri, S., Hamzah, D., \&Yusuf, R. (2012). Implementation of Total Quality Management and Its Effect on Organizational Performance of Manufacturing Industries Through Organizational Culture in South Sulawesi, Indonesia. Journal of Business and Management, 5(1), 10-24. https://doi.org/10.9790/487X-0511024

Benavent, F. (2006). TQM Application Through Self Assessment and Learning Some Experience from Two EQA applicants, Quality Management Journal, 13(1), 7-25. https://doi.org/10.1080/10686967.2006.11918535

Bergman, \& Klefsjö (2010). Quality—From Customer Needs to Customer Satisfaction, $2^{\text {nd }}$ ed, Studentlitteratur, Lund.

Black, S. E., Porter, L. J. (1996). Identification of the Critical Factors of TQM. Decision Sciences, 27(1), 1-21. https://doi.org/10.1111/j.1540-5915.1996.tb00841.x

Boon, S., \& Ram, M. (1998). Implementing Quality in Small Firm: An Action Research. Approach, Personnel Review, 27(1), 20-39. https://doi.org/10.1108/00483489810368530

Brah, S., \& Lim, H. (2006). The Effects of Technology and TQM on Performance of Logistics Companies. International Journal of Physical Distribution and logistics management, 36(3), 192-209. https://doi.org/10.1108/09600030610661796

Chandler, G., \& McEvoy, G. (2000). HRM, TQM and Firm Performance in SME. Entrepreneurship Theory and Practice, 25(1), 43-58. https://doi.org/10.1177/104225870002500105

Chibba, A. (2017). Supply Chain Quality Management-Exploring Performance of Manufacturing Organizations, Unpublished PhD thesis, Lulea University of Technology. Sweden.

Escrig-Tena, A. (2004). TQM as Competitive Factor: A Theoretical and Empirical Analysis, International Journal of Quality \&Reliability Management, 21(6), 612-637. https://doi.org/10.1108/02656710410542034

Evans, J. R., \& Lindsay, W. M. (2008). Managing for Quality and Performance Excellence, $7^{\text {th }}$ ed, Mason: Thomson South-Western.

Feng, J., Prajogo, I., \& Sohal, S. (2006). The impact of TQM practices on performance A Comparative Study Between Australian and Singaporean Organizations, European Journal of Innovation Management, 9(3), 269278. https://doi.org/10.1108/14601060610678149

Flynn, B. B., Schroder, R. G., \& Sakakibara, S. (1994). A Framework for Quality Management Research and an Associated Measurement Instrument. Journal of Operations Management, 11(3), 339-366. https://doi.org/10.1016/S0272-6963(97)90004-8

Fotopoulus, C. B., \& Posmas, E. L. (2009). The Impact of Soft \& Hard TQM Elements on Quality Management Results, International Journal of Quality and Reliability Management, 26(2), 150-163. https://doi.org/10.1108/02656710910928798

Fuentes, M., Montes, F. J. L., \& Fernandez, L. M. (2006). Total Quality Management, Strategic Orientation and Organizational Performance: the Case of Spanish Companies. Total Quality Management, 17(3), 303-323. https://doi.org/10.1080/14783360500451358

Gadennem, D., \& Sharma, B. (2002). An Inter- Industry Comparison of TQM Practices and Performance, Managing Service Quality, 12(6), 394-404. https://doi.org/10.1108/09604520210451876

Hackman, J., \&Wageman, R. (1995). Total Quality Management, Empirical Conceptual and Practical Issues, Administrative Science Quarterly, 40(2), 310-342.

Hair, J., Yoseph, F., Rolph, E., Anderson, R., \& Black, W. (1998). Multivariate Data Analysis, $5^{\text {th }}$ ed, New Jersey: Prentice-Hall, Inc.

Hassan, M., Malik, A. A., \& Faiz, M. F. (2012). An Empirical Assessment of Service Quality and its Relationship with Customer loyalty, Evidence from the Telecom Sector of Pakistan. International Journal of Asian Social Sciences, 2(6), 231-248.

Hoang, D. T., Igel, B., \& Laosirihongthong, T. (2006). The Impact of Total Quality Management on Innovation: 
Findings from A Developing Country. International Journal Quality and Reliability Management, 23(9), 1092-1117. https://doi.org/10.1108/02656710610704230

Honarpour, A., Jusoh, A., \& Nor, K. (2012). Knowledge Management, Total Quality Management and Innovation:A New Look. Journal of Technology Management and Innovation, 7(3), $22-31$. https://doi.org/10.4067/S0718-27242012000300003

Hossain, M. M., Tasnim, M., \& Hasan, M. (2017). Is Quality Ensuring to Get Competitive Advantage In Auto Manufacturing Industries? A Study of Volvo Group. American Journal of Industrial and Business Management, 7, 48-68. https://doi.org/1010.4236/ajibm.2017.71005

Huarng, F., \& Chen, Y. T. (2002). Relationships of TQM Philosophy, Methods, and Performance. Industrial Management \& Data System, 102(4), 226-234. https://doi.org/10.1108/02635570210423271

Hung, R. Y. Y., Lien, B. Y. H., Yang, B., Wu, C. M., \& Kuo, Y. M. (2011). Impact of TQM and Organizational learning on Innovation Performance in the High-tech Industry. International Business Review, 20(2), 213 225.

Jabnoun, N., \& Sedrani, K. (2005). TQM, Culture and Performance in UAE Manufacturing Firms. Quality Management Journal, 12(4), 8-20. https://doi.org/10.1080/10686967.2005.11919267

Kanji, G. (1990). Total Quality Management: The Second Industrial Revolution. Total Quality Management, 1, 311. https://doi.org/10.1080/09544129000000001

Kaynak, H. (2000). The Relationship Between Total Quality Management Practices and Their Effect on Firm Performance. Journal of Operation Management, 21(3), 405-435. https://doi.org/10.1016/S02726963(03)00004-4

Korankye, A. (2013). Total Quality Management: A Source of Competitive Advantage. A Comparative Study of Manufacturing and Service Firms in China. International Journal of Asian Social Science, 3(6), 1293-1305.

Kumar, V., Choisne, F., Grosbois, D., \& Kumar, U. (2009). Impact of TQM on Company's Performance. International Journal of Quality \& Reliability Management, 26(1), 23-37. https://doi.org/10.1108/02656710910924152

Lakhal, L., Pasin, F., \& Liman, M. (2006). Quality Management Practices and Their Impact on Performance. International Journal of Quality and Reliability management, 23(6), 625-646.

Motwani, J. (2001). Measuring Critical Factor of TQM. Measuring Business Excellence, 5(2), 27-30. https://doi.org/10.1108/13683040110397284

Musran, M. (2013) The Impact of TQM practices Towards Competitive Advantage and Organizational Performance. Pak. J. Commer. Soc. Sci., 7(1), 184-197.

Oakland, J. S. (2000). Total Quality Management-Text with Cases ( $2^{\text {nd }}$ ed). Butterworth Heinemann.

Porter, M. E. (1985). Competitive Advantage: Creating and Sustaining Superior Performance, New York, USA: The Free Press.

Prajogo, D. I. (2005). The Comparative Analysis of TQM Practices and Quality Performance Between Manufacturing and Service Firms. International Journal of Service Industry Management, 16, $217-228$. https://doi.org/10.1108/09564230510601378.

Rad, A. M. (2006). The Impact of Organizational Culture on the Successful Implementation of Total Quality Management. The TQM Magazine, 18, 606-625. https://doi.org/10.1108/09544780610707101

Rawashdeh, A. (2014). TQM as a Source of Bank Performance and Competitive Advantage in Jordanian Banking Sector. European Scientific Journal, 10(22), 148-157.

Ray, S., Nanda, C., \& Ota, R. (2016). Total Quality Management: A need for a Sustainable Competitive Advantage, International Journal of Commerce. Business and Management, 5(3), 158-166.

Reed, R., Lemak, D. J., \& Mero, N. P. (2000). Total Quality Management and Sustainable Competitive Advantage. Journal of Quality Management, 5(1), 5-26. https://doi.org/10.1016/S1084-8568(00)00010-9

Sang, C. (2005). Relationship Between HRM Practices and the Perception of Organizational Performance ,Roles of Management Style, Social Capital, and Culture: Comparison Between Manufacturing Firms in Cambodia and Taiwan, UnPublished Master Thesis. National Cheng Kung University, Tainan, Taiwan.

Sashkin, M., \& Kiser, K. (1992). What is TQM? Executive Excellence, 9, 11-17. 
Shu, L., \& Ta chien, H. (2007). Knowledge Transfer and Competitive Advantage on Environmental Uncertainty: An Empirical Study of the Taiwan Semiconductor Industry. Technovation, 27(6-7), 402-411. https://doi.org/10.1016/j.technovation.2007.02.005

Sila, I. (2007). Examining the Effects of Contextual Factors on TQM and Performance Through the Lens of Organizational Theories: An Empirical Study. Journal of Operations Management, 25, 83-109. https://doi.org/10.1016/j.jom.2006.02.003

Sila, I., \& Ebrahimpour, M. (2005). Critical linkages Among TQM Factors and Business Results. International Journal of Operations \& Production Management, 25(11), 1123-1155. https://doi.org/10.1108/01443570510626925.

Stock, G., Greis, N., \& Kasarda, J. (2000). Enterprise logistics and Supply Chain Structure: The Role of Fit. Journal of Operation Management, 18, 531-547. https://doi.org/10.1016/S0272-6963(00)00035-8

Suhong, L., Bhanu, N., Ragu, N., \& Subba, R. (2006). The impact of supply chain management practices on competitive advantage and organizational performance. Omega Journal, 34(2), Pp107-124. https://doi.org/10.1016/j.omega.2004.08.002

Tracey, M., Vonderembse, M. A., \& Lim, J. S. (1999). Manufacturing technology and strategy formulation: Keys to enhancing competitiveness and improving performance. Journal of Operation Management, 17, 411-428. https://doi.org/10.1016/S0272-6963(98)00045-X

Way, S., \& Johnson, D. (2005). Theorizing About the Impact of Strategic Human Resource Management. Human Resource_Management_Review, 1(19), 1- 13. https://doi.org/10.1016/j.hrmr.2005.01.004

Yang, C. C. (2006). The Impact of Human Resource Management Practices on The Implementation of Total Quality Management. The TQM Magazine, 18, 162-173. https://doi.org/10.1108/09544780610647874

Zairi, M., \& Youssef, M. (1995). Benchmarking Critical Factors for TQM: Part I: Theory and Foundation. Benchmarking for Quality Management and Technology, 5-20. https://doi.org/10.1108/14635779510081616

Zakuan, N., Yusof, S., Laosirihongthong, T., \& Shaharoun, A. (2010). Proposed Relationship of TQM and Organizational Performance Using Structured Equation Modeling. Total Quality Management, 21(2), 185203. https://doi.org/10.1080/14783360903550020

Zehir, C., Ertosunb, Ö. G., Zehir, S., \& Müceldilli, B. (2012). Total Quality Management Practices' Effects on Quality Performance and Innovative Performance. Procedia - Social and Behavioral Sciences, 41, 273-280. https://doi.org/10.1016/j.sbspro.2012.04.031

Zhang, Z. (2000). Implementation of Total Quality Management: An Empirical Study of Chinese Manufacturing Firms, unpublished PhD thesis, Groningen, China. https://doi.org/10.1108/02656710010315247

\section{Copyrights}

Copyright for this article is retained by the author(s), with first publication rights granted to the journal.

This is an open-access article distributed under the terms and conditions of the Creative Commons Attribution license (http://creativecommons.org/licenses/by/4.0/). 